\title{
Performance of pilot-scale microbial fuel cells treating wastewater with associated bioenergy production in the Caribbean context
}

\author{
Kiran Tota-Maharaj ${ }^{1} \cdot{\text { Parneet } \text { Paul }^{2}}^{2}$
}

Received: 3 December 2014/ Accepted: 8 March 2015/Published online: 19 March 2015

(C) The Author(s) 2015. This article is published with open access at Springerlink.com

\begin{abstract}
Microbial fuel cell (MFC) technology represents a form of renewable energy that generates bioelectricity from what would otherwise be considered a waste stream. MFCs may be ideally suited to the small island developing state (SIDS) context, such as Trinidad and Tobago where seawater as the main electrolyte is readily available, and economically renewable and sustainable electricity is also deemed a priority. Hence this project tested two identical laboratory-scaled MFC systems that were specifically designed and developed for the Caribbean regional context. They consisted of two separate chambers: an anaerobic anodic chamber inoculated with wastewater and an aerobic cathodic chamber separated by a proton exchange membrane. Domestic wastewater from two various wastewater treatment plants inflow (after screening) was placed into the anodic chamber, and seawater from the Atlantic Ocean and Gulf of Paria placed into the cathodic chambers, respectively, with the bacteria present in the wastewater attached to the anode. Experimental results demonstrated that the bacterial degradation of the wastewaters as substrate induced an electron flow through the electrodes producing bioelectricity whilst simultaneously reducing the organic matter as biochemical oxygen demand
\end{abstract}

Parneet Paul

parneet.paul@brunel.ac.uk

Kiran Tota-Maharaj

Maharaj@greenwich.ac.uk

1 Department of Engineering Science, Faculty of Engineering and Science, University of Greenwich, Medway Campus, Chatham Maritime, Kent ME4 4TB, UK

2 Department of Mechanical, Aerospace, and Civil Engineering, Water Sustainability Research Centre, Brunel University London, Uxbridge, Middlesex UB8 3PH, UK and chemical oxygen demand by 30 to $75 \%$. The average bioenergy output for both systems was 84 and $96 \mathrm{~mW} / \mathrm{m}^{2}$, respectively. This study demonstrated the potential for simultaneous bioenergy production and wastewater treatment in the SIDS context.

Keywords Wastewater - Treatment - Bioenergy · Bioelectricity $\cdot$ Microbial fuel cell (MFC) - Small island developing state (SIDS)

\section{Introduction}

Rapid population increase, urbanisation and industrialisation in the major cities of most developing countries have resulted in deterioration of water quality and shortages of fresh water supplies [1]. In the African continent alone, 115 people die every hour from diseases linked to poor sanitation, poor hygiene and contaminated water and approximately 1.2 billion people live in areas where drinking water is physically scarce [2]. In a similar manner and again, globally speaking, there has been a rapid increase in energy demand over the last few decades. This has led to a greater interest in the development of sustainable energy production especially and more recently by several Caribbean nations over the last few years. Depleting reserves of fossil fuels across Trinidad and Tobago and the environmental impact of their use to produce energy are leading to a search for novel renewable energy technologies. Moreover most wastewater generated is discharged without any treatment. Whilst technologies for wastewater treatment are well established in industrialised countries, the same technologies have often not been successfully applied in a typical developing country scenario. This situation is further exacerbated for the unique context of a small island 
developing state (SIDS) such as is the case with many nations within the Caribbean region. The reasons are myriad, but key amongst these are non-enforcement of environmental regulations and the high cost of the installation and operation of centralised treatment systems.

The lack of sustainability of current fossil fuel-centred energy strategies and safety issues across Trinidad and Tobago will eventually result in a shift in energy policies. Thus, the need for alternative non-fossil fuel-based technologies is essential as is the need for research along these lines so that promising alternatives are developed. Therefore, it is important to investigate novel treatment technologies especially decentralised options that not only effectively treat the influent wastewater stream but which are also low-energy usage systems.

It must be remembered that due to global and regional climate change effects and green-house gas emissions, a radical rethink is needed on how global water is abstracted, treated and supplied to householders, businesses and industries alike. Current hydrosystems have several constraints meaning that they will become increasingly unsustainable and expensive especially as good quality potable water is now universally deemed a human right. These constraints include [2]:

1. Climate change and increased green gas emissions leading to excessive droughts and flooding events engendering inconsistency of existing surface and groundwater sources.

2. Increasing costs of treating water to progressively higher water quality standards.

3. Increasing bioconcentration of trace contaminants and synthetic molecules within the water cycle and the environment in general (e.g. trihalomethanes and endocrine disrupting compounds).

4. Reducing groundwater levels and subsequent amounts of aquifer storage.

5. Ever increasing water demand amongst all consumers (i.e. for domestic, commercial, industrial and agricultural use).

In a bid to address all of these issues in a sustainable yet pragmatic manner, this study focuses on one of two possible sources of "free" water since all other sources are almost fully utilised to meet current water demand and will not be able to meet future projected demand. The first source of "free" water is via rainwater harvesting technologies, whilst the second, which this proposal seeks to focus on, is "wastewater treatment and reuse". This second source of "free" water is particularly relevant in the SIDS situation where they often don't have large surface water sources to rely on. However, SIDS nations uniquely do often have abundant and easily accessible seawater sources since they are surrounded by it, and SIDS nations ideally would like a constant supply of cheap, renewable sources of electricity. Therefore, microbial fuel cell (MFC) technology may well be suited as an innovative solution in the unique SIDS context since MFCs represent a developing technology for simultaneous sustainable energy production and wastewater treatment [3]. MFCs are a promising technology for sustainable energy generation since they are based on the microbial exocellular electron transfer, and the capacity of microbes to transfer electrons produced from the metabolic oxidation of organic substrates to insoluble, extracellular electron-accepting compounds [4]. Hence this project tests two identical laboratory-scaled MFC systems that were specifically designed and developed for the Caribbean regional context.

Wastewater within the southern Caribbean islands of Trinidad and Tobago contains various contaminants and pollutants that need to be removed by the regulations of the Environmental Management Authority (EMA) by utilising a combination of traditional physical processes coupled with biological oxidation processes (with sometimes chemical dosing used as well) before the treated effluent can be discharged to either surface water courses, or within the ground waters or into coastal zones. MFC technology represents a novel form of generating renewable energy via bioelectricity from what would otherwise be considered a waste stream. Even though they are still in the early stages of their development cycle, they are thought to potentially offer a true alternative to traditional fossil fuel energy generation processes [4]. This technology uses bacteria already present in wastewater as the catalysts to generate the electricity whilst simultaneously treating the wastewater. Consequently, a combination of both bioenergy production and wastewater treatment would reduce the downstream cost of treating primary effluent wastewater. Hence MFCs present a feasible option for simultaneous wastewater treatment and bioenergy generation in the SIDS context. MFCs use the concept of bacterial-led oxidation and reduction processes since the microorganisms are already present in the wastewater, and because in this instance the electrolyte phase would be seawater that is readily available for the SIDS situation [5]. MFCs can simultaneously produce bioelectricity and treat wastewater using the naturally occurring bacterial oxidation and reduction processes in the MFC unit. The MFC consists of two chambers (i.e. anode and cathode) filled with wastewater in one and seawater in the other as electrolytes, two electrodes, an external wire circuit and a proton exchange membrane (PEM) as shown in Fig. 1 [6]. In the anodic chamber the wastewater is degraded by the bacterium whilst in the cathodic chamber the seawater present is diluted into brine as water molecules are generated by the application of an external air supply. This whole process generates a bioelectric current. 


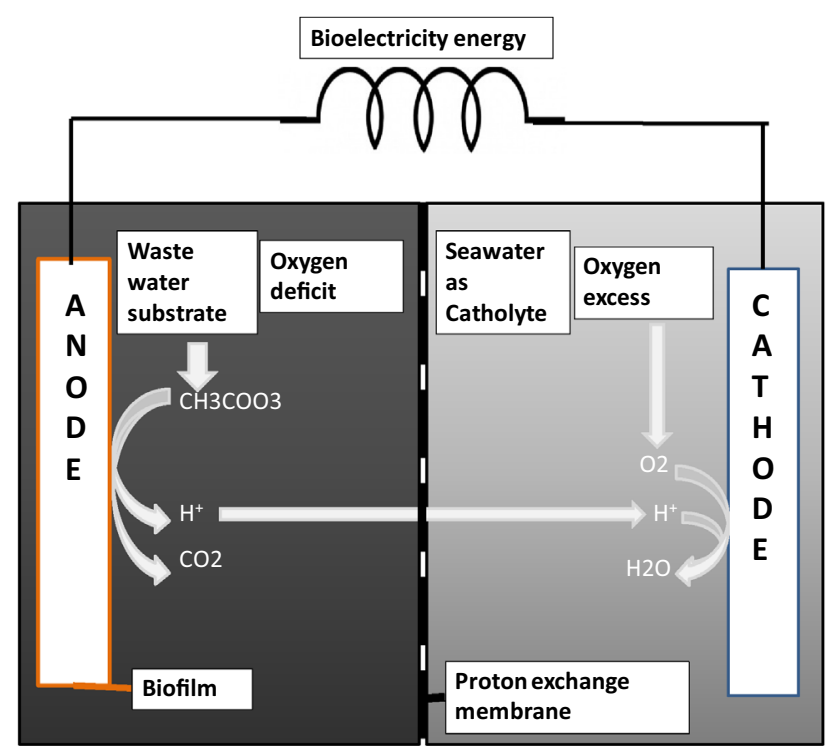

Fig. 1 Schematic of Microbial Fuel Cell based on Direct Bioelectrocatalysis (adapted after [6])

In summary, the aim of this pilot-scale project was to assess bioenergy production for two identical MFCs used for wastewater treatment in order to determine the optimal configuration and operational efficiency of these units from both a SIDS water quality and energy production perspective. The further objectives of this study were to evaluate microbial fuel cell technology in the Caribbean context using a pilot bench-scale unit treating municipal wastewater that was itself constructed using appropriate, sustainable, locally available materials. In this regard the performance of the unit would be monitored by measuring the current and power generated from the cells as a continuous function of time whilst simultaneously observing the wastewater treatment achieved.

The microbes in a MFC may gain all the energy and carbon required for cellular growth from the oxidation of the complex organic material and as such MFC technology has been considered self-sustaining [7]. In other words as long as conditions remain favourable for current production, a MFC system has the potential to produce electricity indefinitely.

\section{Background theory: microbial fuel cell technology for simultaneous energy generation and biological wastewater treatment}

To assess bioelectricity generation from microbes, metabolic pathways governing microbial electron and proton flows must be determined. Typical electrode reactions within MFCs are shown in Eqs. 1 and 2 [7, 8].
Anodic reaction : $\mathrm{CH}_{3} \mathrm{COO}+2 \mathrm{H}_{2} \mathrm{O} \stackrel{\text { microbes }}{\longrightarrow} 2 \mathrm{CO}_{2}$

$$
+7 \mathrm{H}^{+}+8 \mathrm{e}^{-}
$$

Cathodic reaction : $\mathrm{O}_{2}+4 \mathrm{e}^{-}+4 \mathrm{H}^{+} \rightarrow 2 \mathrm{H}_{2} \mathrm{O}$

Microbes in the anodic chamber of a MFC oxidise any added substrates and generate electrons and protons in the process. Carbon dioxide is produced as an oxidation byproduct. The electrons $\left(\mathrm{e}^{-}\right)$are absorbed by the anode and transported to the cathode through an external circuit. After crossing the proton exchange membrane (PEM) or a salt bridge (Fig. 1), the protons enter the cathodic chamber where they combine with oxygen to form water (Eq. 2). Microbes in the anodic zone extract electrons and protons in a dissimilative process of oxidising organic substrates. Bioelectricity generation occurs by keeping microbes separated from oxygen (i.e. under anaerobic conditions) or via end terminal acceptors other than the anode. This requires an anaerobic anodic chamber. Many microorganisms possess the ability to transfer electrons derived from the metabolism of organic matter to the anode. Wastewater and sludge produced from water and wastewater treatment processes are all rich sources for these specific microorganisms. The ideal performance of a MFC depends on the electrochemical reactions that occur between the organic substrate at a low potential such as with wastewater and the final electron acceptor having a high potential such as with oxygen. However, its ideal cell voltage is uncertain because the electrons are transferred to the anode from the organic substrate through a complex respiratory chain that varies from microbe to microbe and even for the same microbe when growth conditions differ. Nevertheless, the actual cell potential is always lower than its equilibrium potential because of irreversible losses in any system $[7,8]$.

\section{Materials and method}

Figure 2 illustrates the configurations of the two identical MFCs used in this study that consisted of an anode, cathode, the PEM and a multimeter that measures voltage and current across the unit. Air pumps were connected to the cathodic chamber of the fuel cell. The MFCs used graphite for both electrodes and the PEM used was a Nafion ion exchange membrane.

Most MFCs have a PEM that separates the anodic and cathodic chambers and acts as a barrier to oxygen, but allows protons (i.e. $\mathrm{H}^{+}$ions) to pass through and be delivered from the anode to the cathode cell. Thus, a typical twochamber MFC consists of an anode and cathode that are placed in separate cells/chambers partitioned by a PEM. The anode is supplied with influent wastewater that contains the microorganisms required for the bioelectrocatalysis 


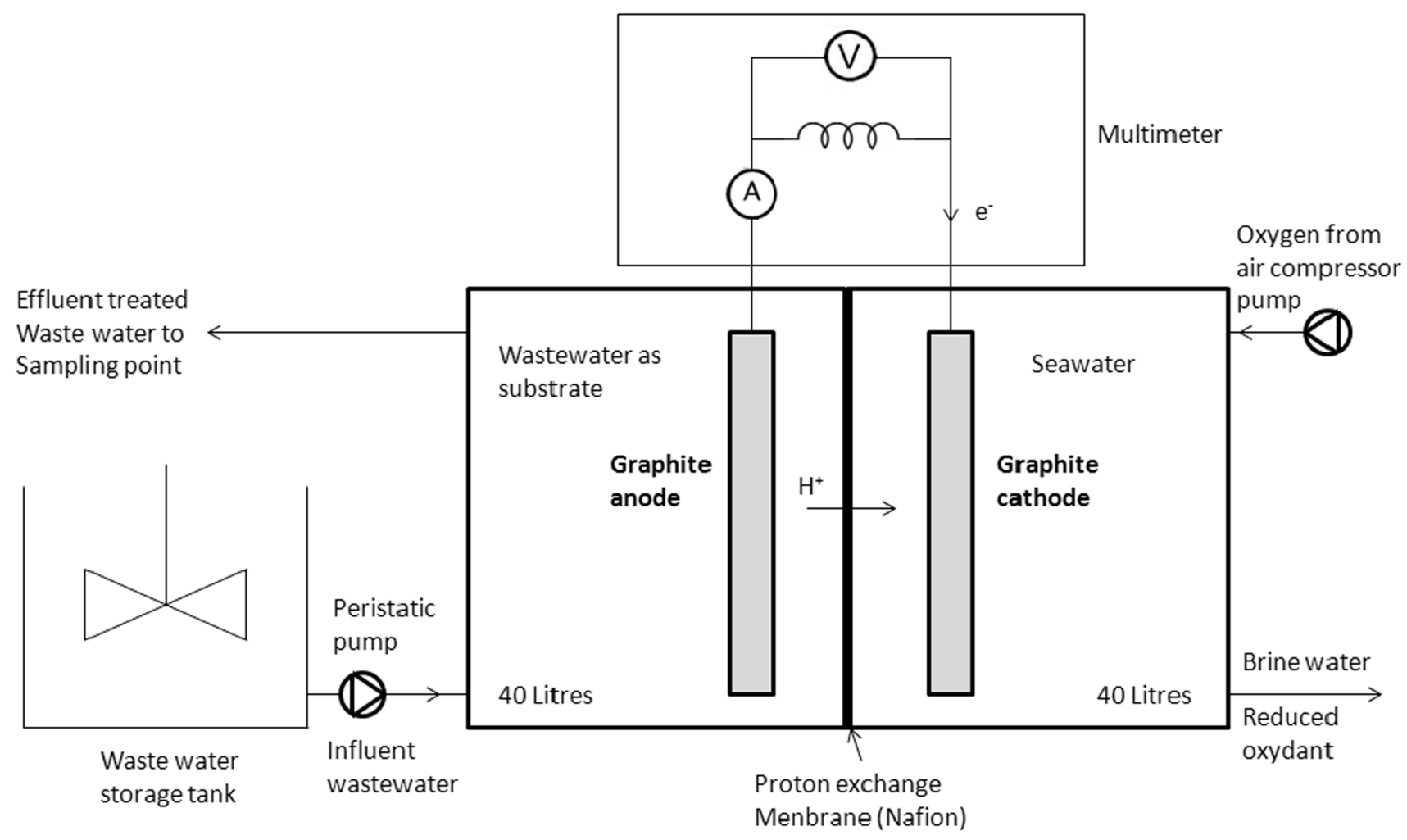

Fig. 2 Experimental configuration of microbial fuel cells used at laboratory pilot scale (adapted after [3])

process [8]. The graphite anode oxidises the substrate-producing protons of hydrogen and an effluent of carbon dioxide. Simultaneously the graphite cathode receives the protons through the PEM, whilst reducing the oxygen present in this saltwater chamber that is supplied by an external air pump. Two MFC devices were constructed with one using seawater from the Atlantic Ocean and the second system using seawater from the Gulf of Paria. Both MFCs contained the same Nafion PEM and graphite electrodes, and were of the same size and scale to allow comparison of results.

Full-strength domestic wastewater was collected as influent once per week from two of the Trinidad and Tobago Water and Sewerage Authority's (WASA) municipal wastewater treatment plants (WWTPs) whose characteristics are depicted in Table 1. The wastewater used as inoculum into the MFCs had no modifications made such as $\mathrm{pH}$ adjustment, addition of nutrients or even dilution. The entire setup was left for one hour for stabilisation to occur, and the reading of the multimeter was noted down twice daily for a maximum of 12 days when wastewater would be exchanged.

Regular water quality analysis was completed for the wastewater influent into the MFC and for the treated outflow from October 2012 to August 2013 including the measurement of $\mathrm{pH}$, temperature, suspended solids,
Table 1 Characteristics of Domestic Wastewater Treatment Plants (WWTPs) from the Water and Sewerage Authority (WASA), Trinidad (October 2012 to July 2013)

\begin{tabular}{llll}
\hline Characteristics & Unit & WWTP (A) & WWTP (B) \\
\hline $\mathrm{pH}$ & - & 7.83 & 7.89 \\
Total solids & $\mathrm{mg} / \mathrm{l}$ & 1140 & 1856 \\
Total dissolved solids & $\mathrm{mg} / \mathrm{l}$ & 980 & 974 \\
BOD $_{5}$ & $\mathrm{mg} / \mathrm{l}$ & 260 & 192 \\
COD & $\mathrm{mg} / \mathrm{l}$ & 954 & 878 \\
Chlorides & $\mathrm{mg} / \mathrm{l}$ & 262 & 232 \\
\hline
\end{tabular}

ammonia, nitrites, nitrates, phosphates, chlorides, chemical oxygen demand (COD) and biochemical oxygen demand (BOD). The concentrations of ammonia, nitrite, nitrate, orthophosphate, COD and suspended solids were determined using a Hach Lange DR 2800 spectrophotometer according to United Stated Environment Protections Agency approved standards for wastewater analysis $[9,10]$.

Water sample temperature and $\mathrm{pH}$ were measured immediately after collecting the samples (i.e. from influent and effluent) with model WTW Var metre handheld $\mathrm{pH} /$ $\mathrm{mV} /$ Temperature metre manufactured by WissenschaftlichTechnische Werkstätten GmbH, Weilheim, Germany.

COD was measured using Hach's USEPA-approved dichromate COD Method $[9,10]$. Globally it is one of the 
most widely used methods as it allows easy process monitoring and reporting of wastewater samples. The Hach Lange DRB200 Reactor (Heating block) is preheated to $150{ }^{\circ} \mathrm{C}$. $100 \mathrm{ml}$ of inflow and outflow water samples is mixed for $30 \mathrm{~s}$. Thereafter $2.0 \mathrm{ml}$ is pipetted into a vial. The vial is inverted gently several times and placed into the DRB200 reactor to be heated for approximately $2 \mathrm{~h}$. Next the sample is cooled for $20 \mathrm{~min}$ to approximately $120{ }^{\circ} \mathrm{C}$ or less. The outside of the vial is cleaned with ethanol using a tissue and then inserted into the spectrophotometer whereby the instrument reads the barcode and results are coded as $\mathrm{mg} / \mathrm{l}$ of COD.

The biochemical oxygen demand $\left(\mathrm{BOD}_{5}\right)$ was determined using the OxiTOP IS 12-6 system supplied by WTW (Wissenschaftlich-Technische-Werkstatten GmbG, Wielheim, Germany). The system uses a piezo-resistive measure of pressure differences from a respirometric method based on carbon dioxide produced within the bottle. A nutrient inhibitor was added to suppress the oxidation of ammonia to nitrates/nitrites (i.e. nitrification inhibitor $N$-allylthiourea). The pressure changes when sodium hydroxide transforms into sodium carbonate. Generated carbon dioxide is then removed by adding sodium hydroxide tablets. The pressure changes are recorded by an electronic data logger and measured over a five-day period at a constant temperature of $20{ }^{\circ} \mathrm{C}$. 0.51 of samples were used in the BOD5 tests, and they were taken from both the MFCs influent and effluent, respectively. After 30 min of aeration by air pumps, a nutrient inhibitor was added to the samples and bottles were incubated at a constant temperature for 5 days. This method proved to be simple to operate, allowed improved controllability and non-toxicity of samples, and had a broad measurement range up to $4000 \mathrm{mg} / \mathrm{l}$ BOD. Since the measured pressure is automatically converted, the values can be directly read as $\mathrm{mg} / \mathrm{l} \mathrm{BOD}$.

\section{Results and discussion}

Both of the dual-chambered MFC units were run in parallel and simultaneously. The MFCs were operated by separately feeding domestic wastewater with similar but fluctuating concentrations. The effects of wastewater concentrations on COD, BOD and ammonia-nitrogen removal efficiency and current generation were observed.

Figure 3 shows the water quality analysis results for both MFC units. In terms of the mean COD inflow and outflow values, it can be clearly seen that on average a $50 \%$ reduction in COD is achieved consistently for both units. Thus, these early results indicate that even with weakly loaded systems, a MFC system has great potential as a wastewater treatment process since organic loadings of
COD can be easily converted into electricity with a concomitant reduction of excess sludge production.

Ammonia removal was consistent and occurred for both MFC systems. Figure 3 also presents the mean inflow and outflow of ammonium ion concentrations and shows average decreasing concentrations of approximately $50 \%$ for this weakly loaded system. Ammoniacal nitrogen $\left(\mathrm{NH}_{4}-\mathrm{N}\right)$ as a nutrient is another key wastewater quality parameter. This determinant is used to efficiently control water and wastewater treatment processes and to demonstrate compliance to EMA-imposed discharge consents in the Trinidad and Tobago situation. It can also be used to indicate the presence of untreated sewage at points of abstraction and infer associated risk from pathogens. As can be seen the mean removal efficiency for MFC 1 was only very slightly greater than that of MFC 2.

Again in Fig. 3, the mean inflow and outflow BOD concentration was determined and showed average decreasing concentrations of approximately $50 \%$ for both MFCs, with MFC 2 performing the best. In fact a linear correlation existed between the strength of the influent organic matter as BOD in the wastewater and the energy yielded from both MFCs, since the bacteria adhering to the anode surface degrade organic matter under anaerobic conditions using bacterial growth and decay kinetics (e.g. Monod reactions). As a consequence of the degradation reaction, carbon dioxide, protons and electrons were produced [5, 11]. The electrons flow through the circuit and the protons pass through the salt bridge (i.e. the PEM) that is attached to the cathode. The protons and electrons react with oxygen on the cathode and become water molecules thereby diluting the seawater to brine [12]. Since the influent BOD ranged from 150 to $300 \mathrm{mg} / \mathrm{l}$ (i.e. a weak domestic sewage) and as both MFCs showed an average removal rate ranging from 40 to $60 \%$, respectively, it can be inferred that a typical normal sewage strength as influent ranging from 300 to $600 \mathrm{mg} / \mathrm{l}$ would achieve improved BOD removal rates with subsequent higher levels of bioelectricity generated due to greater electron transfer to the anode.

The variation in the $\mathrm{pH}$ of the inflow conditions and outflow conditions was also measured and is shown in Table 2. As is apparent and as is expected, there is a mean drop in $\mathrm{pH}$ from slightly alkaline conditions down to neutral conditions as the nutrient load is exhausted.

Figure 4 illustrates the mean monthly power produced from the two identical MFC units. The fluctuation of the power generated is a direct relation to the presence and behaviour of microorganisms and the associated electron flow across the fuel cells. In general and as anticipated a higher bioenergy production was recorded for higher BOD and COD loadings, although localised microbial community variations in individual cells does seem to have a 
Fig. 3 Mean Chemical oxygen demand (mg/l), Ammoniumnitrogen $\left(\mathrm{NH}_{4}-\mathrm{N}, \mathrm{mg} / \mathrm{l}\right)$ and Biochemical oxygen demand $(\mathrm{mg} / \mathrm{l})$ with standard deviations for influent and effluent for both MFC units (October 2012 to August 2013, sample number $=90$ )

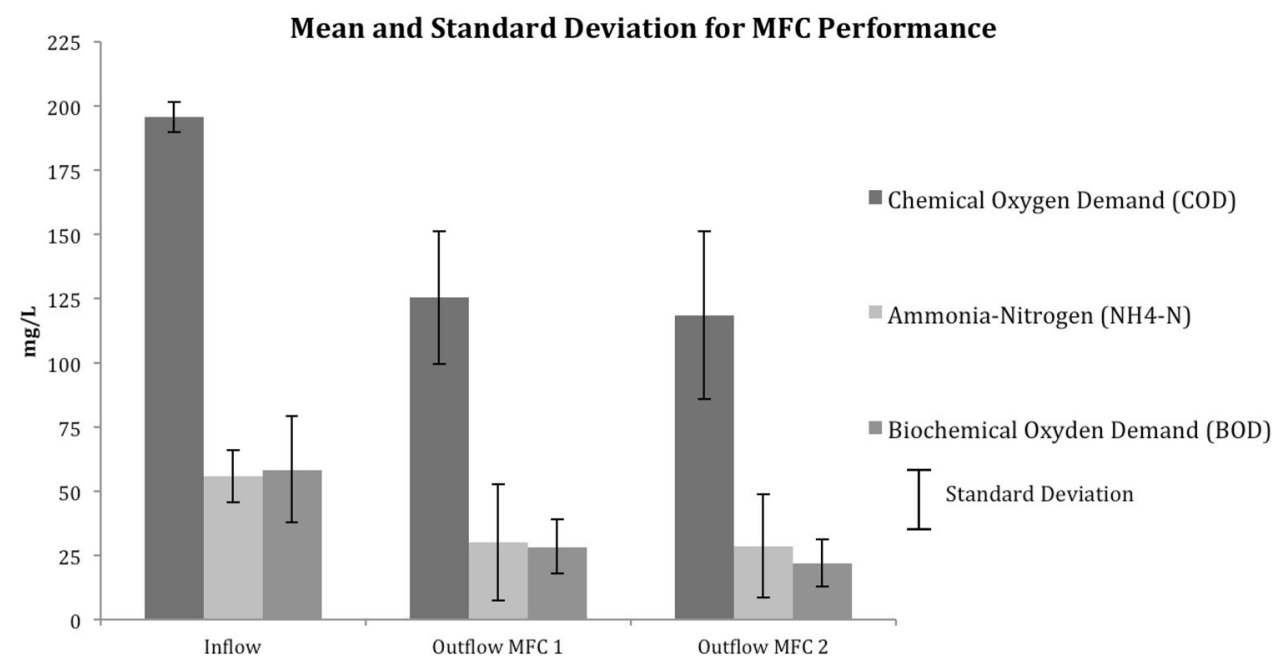

\begin{tabular}{lll}
\hline Direction of flow & Mean pH (90 samples) & Standard deviation of range \\
\hline Inflow & 7.83 & 0.21 \\
Outflow MFC 1 & 6.97 & 0.53 \\
Outflow MFC 2 & 6.84 & 0.41 \\
\hline
\end{tabular}

Table 2 Mean $\mathrm{pH}$ values and standard deviations for inflow and both MFC units from October 2012 to July 2013

Fig. 4 Mean monthly power generated $\left(\mathrm{mW} / \mathrm{m}^{2}\right)$ for both microbial fuel cells (MFCs) from October 2012 to July 2013

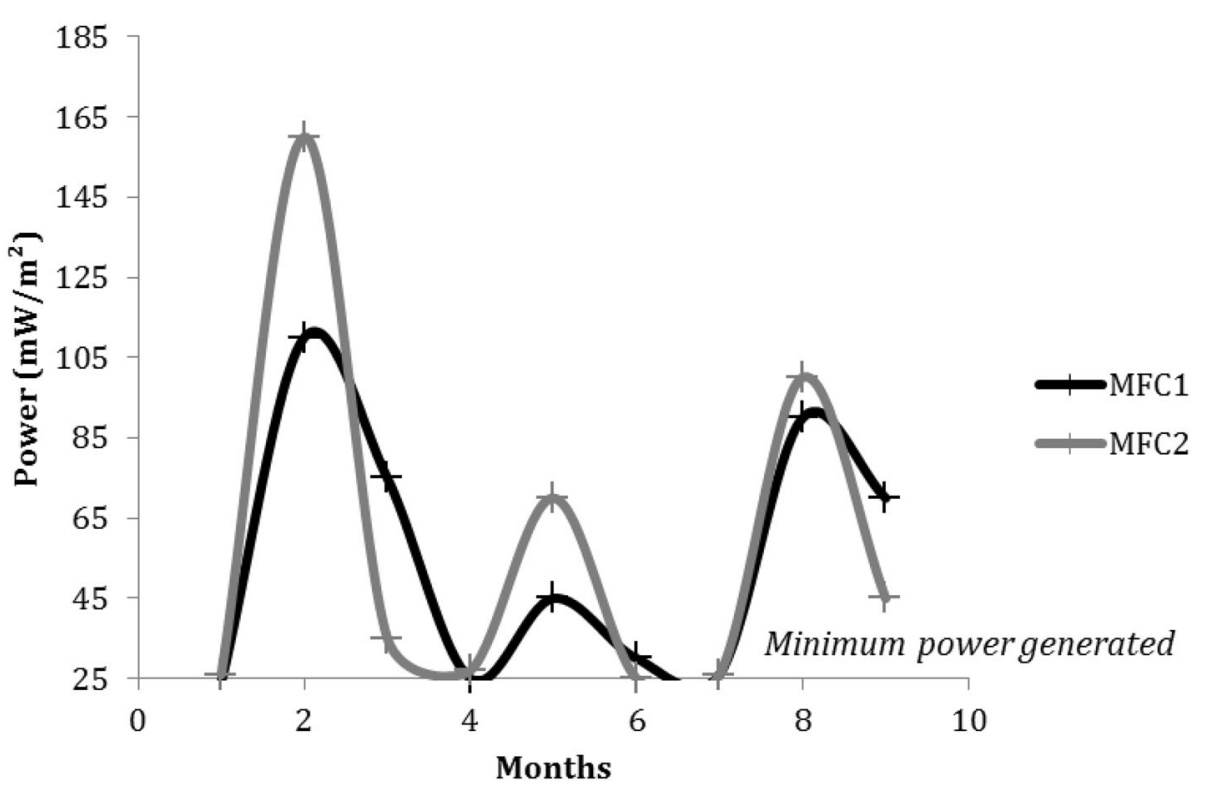

greater impact. The average monthly power output for MFC 1 ranged from 27.2 to $115.8 \mathrm{~mW} / \mathrm{m}^{2}$ with an overall mean power output of $84 \mathrm{~mW} / \mathrm{m}^{2}$ whilst MFC 2 ranged from 26.2 to $175.9 \mathrm{~mW} / \mathrm{m}^{2}$ for power generation monthly with an overall average of $96 \mathrm{~mW} / \mathrm{m}^{2}$.

Coulombic efficiency and power output for MFCs have been reviewed by several authors such as Lee et al. [13], Niessen et al. [14], Pant et al. [15] and Zuo et al [16]. In summary, they found that domestic wastewater at a chemical organic loading strength of $600 \mathrm{mg} / \mathrm{l} \mathrm{had} \mathrm{a} \mathrm{mean}$ current density of $0.06 \mathrm{~mA} / \mathrm{cm}^{2}$, whilst brewery wastewater with an organic strength of $2240 \mathrm{mg} / \mathrm{l}$ had a corresponding average current density of $0.2 \mathrm{~mA} / \mathrm{cm}^{2}$. The current generation for MFC 1 and MFC 2 is illustrated in Fig. 5. Both MFC 1 and MFC 2 were batch fed with wastewater samples at similar conditions in order to support the formation of biomass and subsequent electricity. The MFCs were continuously monitored during the entire 
Fig. 5 Daily electric current $(\mathrm{mA})$ generation for both MFCs treating domestic wastewater from October 2012 to January 2014 (sample number, $n=90$ )

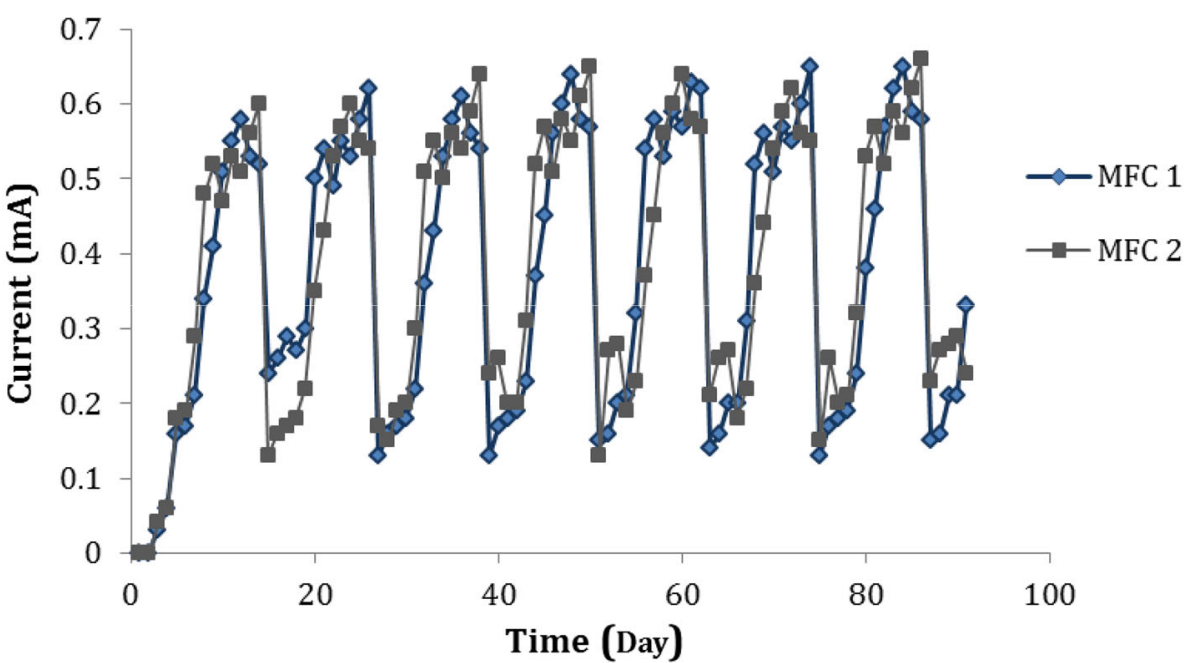

experimental period and readings were logged at the end of each twenty-four period with the inoculation time being considered as time zero. The readings were noted down for 90 days of MFC operation. Higher bioelectricity generation can be as a result of more abundant electron acceptors (i.e. oxygen availability). The full-strength wastewater used in the anodic chambers showed that the current gradually increased for a few days, and then there was a decline in electric current production. The range of current produced was $0.1-0.67 \mathrm{~mA}$, respectively with variations in the current $(\mathrm{mA})$ generation due to the availability of less oxidisable substrates within the wastewater samples.

The difference in power generation for identical MFC units illustrates that the bioelectricity generated was directly proportional to both the variability in wastewater inflow quality and the salt content of the seawater source used. Furthermore, small differences in lab-scale system setup can considerably influence energy production rates although the substrate degradation rates were not greatly impacted upon. For a large-scale MFC setup this situation may not arise since economies-of-scale issues may mean localised biofilm fouling may be regularised on the anode and especially on the PEM as it dictates proton passage.

\section{Conclusions and future outlook}

Experimental results of this research demonstrated that the bacteria present in two various sources of domestic wastewater allowed for an electron flow through the electrodes producing bioelectricity and subsequently reduced 30-80\% of organic matter (as BOD and COD) present. The MFC technology has shown to be a viable technology at laboratory scale for treating urban wastewater of varying strengths and produced a constant but variable production of bioenergy for the SIDS context. The project expands the knowledge of existing technologies in the hopes of improving and optimising water consumption, treatment and energy generation and usage in the Caribbean region. Performance of the two-chamber MFC system demonstrated its effectiveness for simultaneous wastewater treatment and bioelectricity production. It is envisaged that future developments of MFCs can lead to more promising results and the technology eventually made feasible for combined large-scale wastewater treatment and sustainable energy generation.

Follow-on research should focus on two main areas:

- Optimisation of the bioelectricity energy generation mechanism so that the wastewater treatment process can be largely self-sustaining. This would mean comparing the typical energy needs of traditional wastewater treatment processes in the Caribbean region using typical municipal and industrial waste streams with possible MFC bioelectricity generation setups to ascertain if a zero-energy system could be eventually developed.

- Measuring microbial species diversity and biofilm make-up on the anode and PEM to ascertain their impact, if any, on bioelectricity generation rates and simultaneous organic substrate removal rates.

- Using the abundance of solar energy in the Caribbean SIDS scenario to preheat the wastewater influent via simple glass tubes coupled with aluminium reflector solar collector/heat exchanger systems, so that bacterial species obtained would be in the thermophilic range to ascertain if bioelectricity generation rates could be improved upon.

Acknowledgments The authors would like to thank Dr. Denver Cheddie, Head of the Department of Utilities Engineering at the 
University of Trinidad and Tobago, for providing support and partially funding this research initiative. The project was also supported by Key North Engineering, St. Augustine, Trinidad, West Indies.

Open Access This article is distributed under the terms of the Creative Commons Attribution License which permits any use, distribution, and reproduction in any medium, provided the original author(s) and the source are credited.

\section{References}

1. Tayler, K.: Strategies for improved water supply in India and Pakistan. Proc. ICE Munic. Eng. 161(4), 239-246 (2008)

2. UN: International Decade for Action "Water for Life" 2005-2015, UNESDA website. http://www.un.org/water forlifedecade/africa.shtml (2014). Assessed 20th March 2014

3. Logan, B.E.: Microbial fuel cells. Wiley Interscience, New Jersey (2008)

4. Parthasarathy, V., Chellaram, C.: Microbial fuel cells as an alternate strategy for sustainable energy generation. Biosci. Biotechnol. Res. Asia 11(1), 249-252 (2014)

5. Feng, Y., Wang, X., Logan, B.E., Lee, H.: Brewery wastewater treatment using air-cathode microbial fuel cells. Appl. Microbiol. Biotechnol. 78(5), 873-880 (2008)

6. Huang, L.P., Logan, B.E.: Electricity generation and treatment of paper recycling wastewater using microbial fuel cells. Appl. Microbiol. Biotechnol. 80(2), 349-355 (2008)

7. Lovley, D.R.: Bug juice: harvesting electricity with microorganisms. Nat. Rev. Microbiol. 4, 497-508 (2006)

8. Min, B., Logan, B.E.: Continuous electricity generation from domestic wastewater and organic substrates in a flat plate
Microbial fuel cell. Environ. Sci. Technol. 38(21), 5809-5814 (2004)

9. Hach.: HachCompanyDR 2800 Portable Spectrophotometer User's manual. http://www.hach.com/asset-get.download.jsa?id= 7639982019 (2014). Accessed 17 July 2014

10. US EPA: United Stated Environmental Protections Agency (Analytical Methods and Laboratories). http://water.epa.gov/sci tech/methods/ (2011)

11. Logan, B.E., Regan, J.M.: Electricity-productions bacterial communities in microbial fuel cells. Trends Microbiol. 14(12), 512-518 (2006)

12. Mohan, S.V., Saravanan, R., Veer Raghavulu, S., Mohanakrishna, G., Sarmaet, P.N., et al.: Bioelectricity production from wastewater treatment in dual chambered microbial fuel cell (MFC) using selectively enriched mixed microflora: effect of catholyte. Biores. Technol. 99(3), 596-603 (2008)

13. Lee, H.S., Parameswaran, P., Kato-Marcus, A., Torres, C.I., Rittmann, B.E.: Evaluation of energy-conversion efficiencies in microbial fuel cells (MFCs) utilizing fermentable and non-fermentable substrates. Water Res. 42(6-7), 1501-1510 (2008)

14. Niessen, J., Schröder, U., Scholz, F.: Exploiting complex carbohydrates for microbial electricity generation - a bacterial fuel cell operating on starch. Electrochem. Commun. 6, 955-958 (2004)

15. Pant, D., Van Bogaert, G., Diels, L., Vanbroekhoven, K.: A review of the substrates used in microbial fuel cells (MFCs) for sustainable energy production. Biores. Technol. 101(6), 1533-1543 (2010)

16. Zuo, Y., Maness, P.C., Logan, B.E.: Electricity production from steam-exploded corn stover biomass. Energy Fuels 20, 1716-1721 (2006) 